\title{
Comparative Performance of Fault ride through Controller in Modular Multilevel Converter based HVDC Transmission
}

\author{
Olusegun Olowookere, Yehdego Habtay, Steve Woodhead and Spyros Skarvelis-Kazakos \\ Faculty of Engineering and Science \\ University of Greenwich, Medway,UK \\ O.Olowookere@gre.ac.uk
}

\begin{abstract}
This paper centres on the performance of PI and hysteresis controllers for AC fault ride through for an MMC VSC - HVDC transmission system. In the simulated MMC converter test system, a $600 \mathrm{MW}$ VSC-HVDC transmission line connects two farms, formed from combined offshore wind turbines and wave converters, to the two onshore $\mathrm{AC}$ grids. The model in this study included two $300 \mathrm{kV}$ DC submarine cables with a cable length of $100 \mathrm{~km}$. In the reported simulation a three-phase to ground fault, a single line to ground fault, a double line to ground fault and a line-to-line fault were applied to the onshore AC network. The simulation results reveal reductions in DC voltage overshoot and transient energy with the PI-based controller (compared to the hysteresis controller) for 3- phase to ground, line to ground and line - to - line to ground faults respectively, with no difference for line-to-line faults.
\end{abstract}

Index Terms-PI, Hysteresis, FRT, VSC, HVDC, MMC

\section{INTRODUCTION}

Power generated from renewable resources remains a major component in the provision of a sustainable energy quantity for the future [1]. Wind and wave power are two distinct renewable resources in the UK that can share the same environmental conditions with potential benefits [2]. The quantity of offshore wind power generation is on the increase in the UK. Wave power generation can also have a significant contribution if properly harnessed [3]. The UK has a target of $15 \%$ renewable energy consumption by 2020 which translates to a $29 \mathrm{GW}$ contribution from offshore wind power [4]. However, offshore wind power contributed 5GW to the UK's electricity consumption at the end of 2016 [5]. Offshore wave energy is a major driver of the Scottish Government's $100 \%$ renewable energy target, which translates to $14 \mathrm{GW}$ by 2020 [6]. Combining the power generated from offshore wind and wave farms can be an important contributor to achieving the Government's target of supplying $15 \%$ of the UK's energy from renewable generation by 2020 [7].

There are construction sites for several offshore wind farms in the UK since the commissioning of the Blyth pilot project in December 2000 [8]. One such construction site is the London Array project with an installed capacity of $630 \mathrm{MW}$, which is the largest offshore wind farm in the world [9]. Wave energy has experienced measurable progress despite not being as developed as wind energy. A recent development in wave energy is the Land Installed Marine Power Energy Transmitter
(LIMPET) project in Scotland, UK, which is a major boost to the country's renewable energy [10]. According to the United Kingdom Department of Energy and Climate Change, the projected capacity of wave energy by 2020 is $250 \mathrm{MW}$ [11].

Wind power suffers from intermittency while wave power suffers from variability [12]. The progress of wave energy development is slow because it provides a low power output while requiring large infrastructure investment [13]. Wind power is one of the greatest renewable energy strengths of UK [14]. The incorporation of wave energy systems into offshore wind energy farms has the potential to enhance economies of scale in the power generation systems of the UK [15]. The power generation profile of a combined wind and wave energy farm showed more reliability than that of the single wind farm according to a study in [16]. Offshore wind and wave power are more cost-effective than onshore wind and seashore wave power because of their increased power capacities at reduced installation cost [17].

The offshore AC grid of combined offshore wind and wave farms can be weak because of the fixed rating of power electronic converters capable of reducing the power system inertia of the offshore AC grid. The power system inertia is the response of the $\mathrm{AC}$ system to sudden frequency disturbance [18]. Another indicator of a weak AC grid is a poor short circuit level. The short circuit level refers to the maximum fault current permissible in a power system when a three-phase to ground fault occurs [19].

The DC voltage in an HVDC transmission network increases when an onshore $\mathrm{AC}$ grid fault occurs because of the inability of the onshore VSC converter to push active power to the onshore AC grid. Transient results from the rise in the DC voltage across the VSC capacitor in a short time [20]. There is a need to examine the transient behaviour of the capacitor voltage because of its impact on the devices within the HVDC transmission network [20]. Voltage overshoots result when the voltage rises across the capacitor over expected time [21]. The generation of transient voltage overshoots has impacts on the reliability and availability of the VSC converters, cables, and the filter capacitors [22]. Availability and reliability are major components in deciding the economic and technical capabilities of Round 3 offshore renewable generation. The values of availability and reliability influence the profitability and suitability of the DC grid network. 
The MMC converter topology is a relatively new HVDC converter technology for synthesising high voltage from the switching of several voltage levels [23]. This modularity eliminates the series connection of IGBTs [24-25]. With this arrangement, it is now possible to manufacture converters of ratings above $1 \mathrm{GW}$ capacity [26]. This paper presents the comparative analysis of PI and hysteresis controllers for chopper resistor based DC overvoltage control for fault ride through of 31- level MMC VSC HVDC systems. The simulation study was carried out using MATLAB /SIMULINK.

\section{AC FAULT RIDE THROUGH}

Fault ride-through (FRT) capability refers to the ability of an onshore VSC-converter to remain connected to the DC grid when a fault occurs at the onshore AC grid [27]. This capability permits the VSC-converter to stay connected to the grid even with a voltage change at the point of common coupling of the onshore AC grid during faults [28].

VSC based HVDC is a technology capable of operating at a low AC grid voltage [29]. Transients in the DC grid capacitors caused by lack of active power export of the VSC to the onshore grid are a serious concern on HVDC networks when $\mathrm{AC}$ faults occur at the onshore grid [30]. The power imported from the offshore wind farms remains unaffected during an onshore AC grid fault because the offshore wind turbine network is decoupled from the onshore AC grid by the DC link. This results in power imbalance that increases the voltage in the DC network. The VSC- HVDC capacitors that accommodate the trapped active power require protection within a predefined time limit of the fault. Even though the grid connection of wind farms with VSC based HVDC is the most cost-effective option for a submarine transmission distance of over $50 \mathrm{~km}$, fault ride-through capability is still a crucial obligation for the adoption of VSC- HVDC transmission networks [29].

Fault- ride- through strategies are necessary for the reliable protection of VSC based HVDC transmission. A reliable protection system is an essential contributor to the integration of offshore renewable energy through HVDC link. The available techniques for FRT are power reduction, energy storage and power dissipation.

Achieving FRT by means of power dissipation involves the installation of resistor - based DC choppers close to the onshore VSC station. This technique is the most realistic for FRT implementation. The resistor-based DC chopper is a voltage-controlled power electronic device for managing the dissipation of any undelivered power due to onshore AC faults [31-33]. The rating of the DC choppers and resistor banks must be the same as that of the rating of the VSCs to accommodate the trapped offshore wind and wave power [33].

The power dissipation technique has been considered in this paper for the onshore fault ride through of MMC VSC HVDC systems.

\section{Simulation MODEL}

\section{A. Offshore Wind and Wave farm details}

A 200MW offshore wind farm normally comprises of 100 units of $2 \mathrm{MW}$ turbines. Horizontal upwind turbines were employed in this work because their rotors face the wind to eliminate tower wind shades [34]. The ocean waves often fluctuate and the capability to obtain optimum power is restricted [35]. The most employed means of reducing the power fluctuation is to aggregate a number of incoherent wave energy converters (WEC) [36]. Aggregating 64 incoherent WECs resulted in a reduction in power variation from 3.6 to 1 as reported in [37]. The Darrieus turbine parameters in [38] were re-parameterized for the simulation study.

\section{B. MMC VSC HVDC transmission system for combined offshore wind and wave farms}

This section presents the simulation details of the 4terminal MMC VSC-HVDC system. A controllable threephase voltage source connected to a $600 \mathrm{MVA}, 460 \mathrm{kV} / 370 \mathrm{kV}$ transformer modelled the combined offshore wind and wave farms. This simulation study employed a 31- level MMC for acceptable harmonic attributes. The design calculation for the submodule capacitors considered a $10 \%$ ripple voltage. This study employed a rating of $\pm 300 \mathrm{kV}$ for a current flow of $2 \mathrm{kA}$ for the VSC-HVDC transmission system as suggested by National Grid. The model design of this simulation study employed two $300 \mathrm{kV}$ DC submarine cables with a cable length of $100 \mathrm{~km}$. The short circuit ratio of the voltage source and the phase reactor were 3.5 and $15 \%$ respectively.

A three-phase to ground fault, a single line to ground fault, a double line to ground fault and a line-to-line fault were applied to the onshore $\mathrm{AC}$ network at $1 \mathrm{~s}, 3 \mathrm{~s}, 5 \mathrm{~s}$ and $7 \mathrm{~s}$ respectively. The submarine XLPE cables considered in this study are in accordance with industrial specifications by ABB [39-41].

\section{MMC-VSC HVDC control}

In the MMC converter test system, a 600 MW VSC-HVDC transmission line connects two farms, formed from combined offshore wind turbines and wave converters, to the two onshore $\mathrm{AC}$ grids.

\section{Modelling considerations}

The duration of the changes associated with the fault occurrence is in hundreds of milliseconds [42]. The Electromagnetic Transient (EMT) high-frequency simulation of the constituent parts is suitable for fault analysis, due to its transient capability. The work in this paper involves the investigation of the transients which are evaluated in 140 milliseconds for the power dissipation technique [43].

\section{E. Design of Hysteresis voltage controller}

Hysteresis controllers are very common because of their ease of implementation. A Hysteresis controller configuration has a logic to either completely switch on or off. The hysteresis controller normally operates as a feedback loop scheme.

The hysteresis controller is a single input-single output device that permits an output to oscillate between two predefined boundaries. The controller has a switch offset point above which the controller stays on and a switch on point 
below which the controller stays off. For the Hysteresis application, the switch on point must exceed the switch off point. The control signal of the Hysteresis controller is discontinuous whose operation is in a bang-bang manner for variable system applications. One of the disadvantages of this controller is its variable switching frequency, which can be detrimental to the operation of the power switch, in terms of the switching losses. In this controller, the error signal determines the ripple in accordance with the Hysteresis band. The Hysteresis band (window) controls the switching frequency [44].

\section{F. Design of PI-based voltage controller}

A PI controller is a type of feedback controller generally employed in electrical systems to maintain process parameters about set point, by reducing the error signal to a near-zero value [41]. The PI control effectively combines the regulation of proportional and integral terms for instantaneously keeping the system changes within specified limits. The performance of a PI or two-mode controller depends on its response speed and the steady state error. Equation 1 presents the analytical expression for a PI controller:

$$
P=K p * e p+K i \int(e p * d t)+P x(0)
$$

Where $\mathrm{P}$ is the controller output, ep is the error, $\mathrm{Kp}$ is the proportional gain, $\mathrm{Ki}$ is the integral gain and $\mathrm{Px}(0)$ is the controller's output at the start of the operation.

The simulations involved a range of reference DC voltages for the fault ride through DC voltage control of the PI and hysteresis controllers. The Ziegler-Nichols tuning technique was employed to obtain the optimum gain of the PI controller $\left(\mathrm{K}_{\mathrm{u}}\right)$ and the oscillation period $\left(\mathrm{T}_{\mathrm{u}}\right)$ as 0.00333 and 0.667 respectively. The values $\left(\mathrm{K}_{\mathrm{u}}\right)$ and $\left(\mathrm{T}_{\mathrm{u}}\right)$ resulted in PI controller gains of: $\mathrm{K}_{\mathrm{P}}=0.0015$ and $\mathrm{K}_{i}=0.006$. A cut-off frequency of $2 \mathrm{kHz}$ was applied for the PI- controller.

\section{G. Onshore AC grid}

A voltage source in series with inductive impedance can represent the onshore AC grid [45]. Most of the onshore highvoltage $\mathrm{AC}$ grids in the $\mathrm{UK}$ have $400 \mathrm{kV}$ nominal rating [46]. The threshold SCR for a strong AC grid is 3 [47]. The SCR of the onshore AC grid in this paper was 3.5 for MMC-based converters for high and moderate strength [48]. The grid impedance is an indicator of the short-circuit ratio (SCR) of the Point of Common Coupling (PCC) at the AC grid [49] The values of the onshore $\mathrm{AC}$ grid resistance and inductance for the MMC converters were therefore set to $4.43 \Omega$ and $283 \mathrm{mH}$ respectively.

\section{H. Sub-module capacitor details}

Equation 2 shows the expression of the sub-module capacitor of MMC converter similar to [50]:

$$
C_{S M}=\frac{2 S_{N} E_{M}}{N V_{C}^{2}}
$$

Where $S_{N}, \mathrm{~N}$ and $E_{M}$ are the nominal power of the HVDC, number of modules and capacitor module energy respectively. The sub-module capacitance value computed to meet the $10 \%$ ripple voltage was $583 \mathrm{uF}$.

\section{HVDC Cable modelling}

DC cable circuit modelling involves bipolar configuration of the positive and negative DC voltages. This configuration ensures the improved reliability of the DC grid for the operation of a pole in the case of a defect in the other pole [51]. The DC transmission system can be represented by a pole that can contain the information of the two poles. This simplification was employed in a study in [52] with series resistance, capacitance and inductance. Individual branches of the cable can be shown by a pi-section. A lumped parameter model which considers the lumping together of the resistance, inductance and capacitance to form pi-section was considered in this model. The consideration is suitable for the analysis in this work because the simulation was based on a time step of 50us and the XLPE cable is longer than $10 \mathrm{~km}$ [53]. The cable parameters significantly impact on the performance of the HVDC transmission.

\section{RESULTS AND DISCUSSION}

This section presents the simulation results of the parametric analysis for MMC VSC - HVDC based DC voltage control for two controllers. Figures 1 and 2 show the DC voltage response of the onshore AC grid side 1 for the two controllers for the respective faults for DC voltage set - point of $1.07 \mathrm{pu}$. Table 1 summarises the DC voltage overshoot reduction of the two controllers, reflecting that the PI-based control achieved lower overshoots for the ground faults while there was a balanced result for the line-to-line fault for the two controllers.

Table 1: Summary of simulation results for DC voltage

\begin{tabular}{|c|c|c|c|c|}
\hline Fault & \multicolumn{2}{|c|}{ PI control } & \multicolumn{2}{|c|}{ Hysteresis } \\
\hline & Voltage & $\begin{array}{l}\text { Overshoots } \\
\text { (pu) }\end{array}$ & Voltage & $\begin{array}{l}\text { Overshoots } \\
\text { (pu) }\end{array}$ \\
\hline $\begin{array}{l}\text { Three- } \\
\text { phase to } \\
\text { ground }\end{array}$ & 1.08 & 0.03 & 1.085 & 0.035 \\
\hline $\begin{array}{l}\text { Single } \\
\text { phase to } \\
\text { ground }\end{array}$ & 1.24 & 0.19 & 1.25 & 0.2 \\
\hline $\begin{array}{l}\text { Line to } \\
\text { line to } \\
\text { ground }\end{array}$ & 1.127 & 0.077 & 1.13 & 0.08 \\
\hline $\begin{array}{l}\text { Line to } \\
\text { line }\end{array}$ & 1.25 & 0.2 & 1.25 & 0.2 \\
\hline
\end{tabular}
overshoot during FRT with controller set point of $1.07 \mathrm{pu}$ 


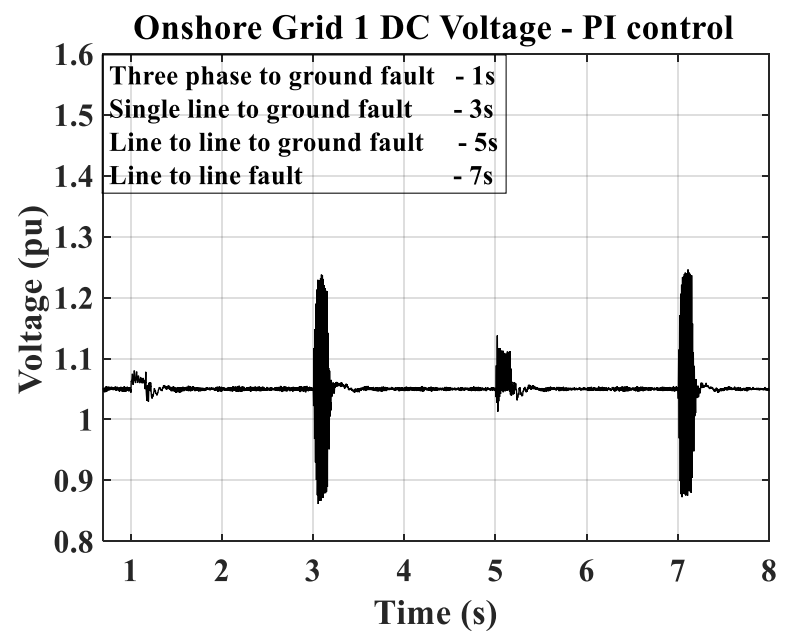

Figure 1: Onshore Grid Side DC Voltage (PI)

The DC voltage overshoot reductions computed from the reflected values in Table 1 of the PI-based controller over the hysteresis controller is presented in Table 2 .

Table 2: summary of DC voltage overshoot reduction achieved by $P I$ controller over hysteresis controller

\begin{tabular}{|l|c|}
\hline Fault type & $\begin{array}{l}\text { Voltage } \\
\text { reduction (\%) }\end{array}$ \\
\hline Three- phase to ground & 14.3 \\
\hline Single line to ground & 5 \\
\hline Line to Line to ground & 3.75 \\
\hline Line to Line & 0 \\
\hline
\end{tabular}

The selection of protection methods affects the failure rate of DC submarine cables [54-56]. Table 3 presents the computed Mean - Time - Between - Failures (MTBF), Mean Time - To Failure (MTTF) and Mean -Time - To - Repair (MTTR) for the evaluation of offshore submarine HVDC cable performance [57]. The three indices are presented in Table 3 where the PI controller showed improvements over the [1] hysteresis controller.

Table 3: Summary of computation of parameter indicators for the simulation study

\begin{tabular}{|c|c|c|c|c|}
\hline Indicators & $\begin{array}{c}\text { Three - } \\
\text { phase to } \\
\text { ground } \\
\text { (PI) }\end{array}$ & $\begin{array}{c}\text { Single } \\
\text { line to } \\
\text { ground } \\
\text { (PI) }\end{array}$ & $\begin{array}{c}\text { Line to } \\
\text { Line to } \\
\text { ground } \\
\text { (PI) }\end{array}$ & $\begin{array}{c}\text { Line to } \\
\text { Line }\end{array}$ \\
\hline $\begin{array}{c}\text { Failure rate } \\
(\%)\end{array}$ & 1 & 0.35 & 0.263 & 0 \\
\hline $\begin{array}{c}\text { MTBF } \\
\text { (years) }\end{array}$ & 2.38 & 0.752 & 0.557 & 0 \\
\hline $\begin{array}{c}\text { MTTF } \\
\text { (years) }\end{array}$ & 2.38 & 0.752 & 0.557 & 0 \\
\hline $\begin{array}{c}\text { Availability } \\
(\%)\end{array}$ & 0.23 & 0.09 & 0.058 & 0 \\
\hline $\begin{array}{c}\text { Reliability } \\
(\%)\end{array}$ & 16.69 & 5.24 & 3.6 & 0 \\
\hline
\end{tabular}

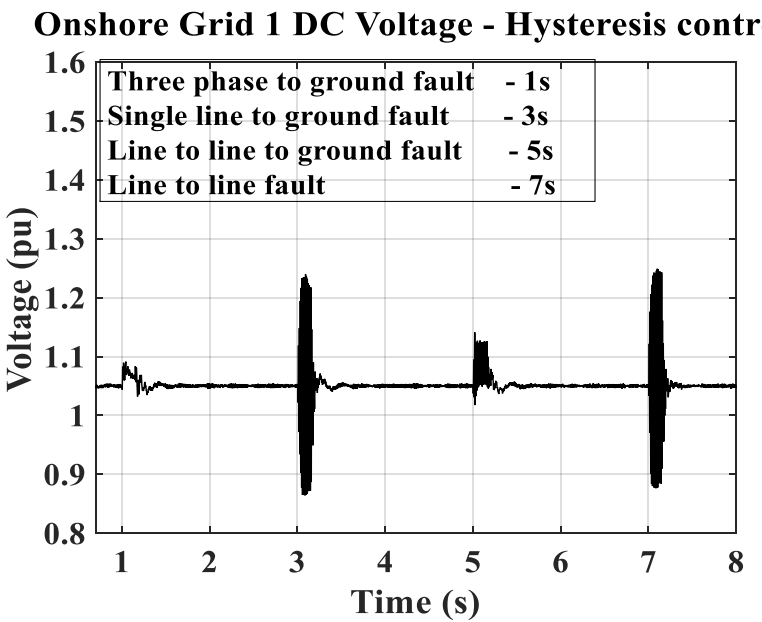

Figure 2: Onshore Grid Side DC Voltage (Hysteresis)

The results of the MMC based transmission system showed that for ground faults, the PI-based controller presented lower DC voltage overshoots than the hysteresis controller did. However, for the line-to-line fault, the two controllers presented comparable responses.

\section{CONCLUSION}

In this simulation study, the performance of two FRT controllers was presented. The comparison of the transient performances of PI-based and hysteresis-based DC voltage control showed that the PI-based response produced a lower DC voltage overshoot response than hysteresis control for ground faults while the hysteresis-based response produced a lower DC voltage overshoot response than PI control for lineto-line fault.

\section{REFERENCES}

H. Park and R. Baldick, "Stochastic generation capacity expansion planning reducing greenhouse gas emissions," IEEE Trans. on Power Systems, vol. 30, no. 2, pp. 1026-1034, March 2015.

T. K. A. Brekken, A. Von Jouanne, and H. Y. Han, "Ocean wave energy overview and research at Oregon state university," in Power Electronics and Machines in Wind Applications, pp. 1-7, Jun. 24-29, 2009.

[3] T. Ahmed, K. Nishida, and M. Nakaoka,"The Potential for Grid Power Integration Offshore Ocean Wave Energy in the UK," The 2010 International Power Electronics Conference, p.3204-3211, June 2010 Carbon Trust, "'Offshore wind power: big challenge, big opportunity Maximising the environmental, economic and security benefits,' Available: https://www.carbontrust.com/media/42162/ctc743offshore-wind-power.pdf

[5] The Crown Estate, "'offshore wind operational reportJanuary - December 2016," Available:

//www.thecrownestate.co.uk/media/1050888/operation alwindreport2017_final.pdf. 
[6] Hi- Energy Highlands and Islands of Scotland harnessing nature's power. Available: http://www.hienergy.org.uk/renewables/wave-energy.

[7] Ofgem, "Electricity Capacity Assessment Report," Company Report, 2013.

[8] N. Nikolaos. (2004): Deepwater offshore wind technologies. Glasgow. University of Strathclyde - [21] $\mathrm{PhD}$

[9] L. Qianjin et al (2008) 'A novel active damping control of TCSC for SSR suppression in a radial corridor,' in, in $3^{\text {rd }}$ International Conf., on Electric Utility [22] Deregulation and Restructuring and Power Technologies, pp. 136-142.

[10] T. Heath, T. J. T. Whittaker \& C.B. Boake, "The [23] Design, construction, and operation of the LIMPET Wave Energy converter (Islay, Scotland),' 4th Wave Power Conference, 2000, Denmark.

[11] X. P. Zhang and P. Zeng, "Marine Energy Technology [24] [Scanning the Issue],' IEEE proceedings, vol, 101, no. 4, pp. 862-865, April 2013.

[12] Z. X. Weng, L. B. Shi, Z. Xu, L. Z. Yao, Y. X. Ni, and M. Bazargan, "Effects of wind power variability and [25] intermittency on power flow,' IEEE Power and Energy society general meeting, pp. 1-7, July 2012.

[13] National Grid Electricity Transmission plc, "Offshore Development Information Statement: Future Scenarios Consultation," February 2011. [Online]. Available: http://www.nationalgrid.com. [Accessed 08 November 2014].

[14] L.C. Cradden, "The Impact of Climate change on Wind Energy Generation in the UK," $\mathrm{PhD}$ Thesis, The University of Edinburgh, 2009.

[15] S. E. B. Elghali, R. Balme, K. L. Saux, M. E. H Benbouzid, J. F. Charpentier, and F. Hauville, "A [28] simulation model for the evaluation of the electrical power potential harnessed by a marine current turbine," IEEE Journal of Oceanic Engineering, vol. 32, no. 4, pp. 786-797, October 2007.

[16] E. Tedeschi, E. Robles, M. Santos, O. Duperray, and F. Salcedo, "Effect of energy storage on a combined wind and wave energy farm,' IEEE Conference on Energy Conversion and Exposition, pp. 2798 - 2804, September 2012.

[17] D. Ahn, S.C. Shin, S.Y. Kim, H. Kharoufi, H.C. Kim, "Comparative evaluation of different offshore wind turbine installation vessels for Korean west-south wind farm,' ' International Journal of Naval Architecture and Ocean Engineering 9 (1), 45-54 January 2017.

[18] P. de Toledo, "Aspects on infeed of multiple HVDC into one AC network," ABB

Power System, HVDC division, Ludvika, Sweden, 2004. [Online]. Available:

https://library.e.abb.com/public/b3b16a30843135a0c1 256fda004aeaee/Aspects_Multiple_Infeed_HVDC_1.p df. [Accessed: 18-November-2016].

[19] National Grid, "System Operability Framework 2014," 2014. [Online]. Available: http://www2.nationalgrid.com/UK/Industry-
information/Future-of-Energy/System-OperabilityFramework/. [Accessed: 17-October-2016].

D. Tremouilles, S. Thijs, N. Mahadeva Iyer, V. Vassilev, P. Roussel, and G. Groeseneken, "Transient voltage overshoot in TLP testing-Real or artifact?" in Proc. EOS/ESD Symp., 2005, pp. 152-160.

T. Smedes and N. Guitard, "Harmful voltage overshoots due to turn-on behaviour of ESD protections during fast transients," in Proc. EOS/ESD Symp., Sep. 2007, pp. 6A.4-1-6A.4-9

S. A. Ali, "Capacitor banks switching transients in power systems," Energy Science Technology, 2(2), pp. 62-73, Nov. 2011.

S. Kouro et al, "Recent advances and industrial applications of multilevel converters,' IEEE Transaction on Industrial Electronics, vol. 57, no. 8, pp. 2553-2580, July 2010.

H. Byung Moon, and J. Jong Kyou, "Switching- level simulation model of MMC-based back-to-back converter for HVDC application,', IEEE conf., pp. 937943, May 2014.

U. N. Gnanarathna, S. K. Chaudhary, A. M. Gale, and R.Teodorescu, "Modular multi-level converter based HVDC system for grid connection of Offshore Wind Power Plant," in IET Conference on AC and DC Power Transmission, pp. 1-5, October 2010.

K. H. Ahmed, and G. P. Adam, "New Modified Staircase Modulation and Capacitor Balancing Strategy of 21-level Modular Multilevel Converter for HVDC Transmission Systems," in 2014 IET Power Electronics, Machines and Drives Conf., April 2014.

[27] L. Xuan, S. Qiang, L. Wenhua, and M. Yulong, "Study on fault ride through capability of wind farm integration J. Zhang, "Research on Flywheel Energy Storage System Using in Power Network," in Proc. Int. Conf. Power Electronics and Drives Systems, PEDS, Nov. 28-01, 2005, vol. 2, pp. 1344-1347.

Y. Wang, $\mathrm{X}$. Su, and $\mathrm{X}$. Han, "Fault ride through control of the wind farm integrated with VSC-HVDC," ICEMS International conf., pp. 267-272, October 2013. J. Wu, S. Zhang, and D. Xu, "Modelling and control of multi-terminal HVDC with offshore wind farm integration and DC chopper-based protection strategies," Industrial Electronics Society, IECON Annual IEEE Conf., pp.1013-1018, November 2013.

I. Erlich, H. Wrede, and C. Feltes, "Dynamic Behaviour of DFIG - Based Wind Turbines during Grid Faults, ' in Power Conversion Conference, pp. 1195 1200, April 2007.

C. Feltes, H. Wrede, F. W. Koch, and I. Erlich, "Enhanced fault ride-through method for wind farms connected to the grid through VSC-based HVDC transmission," Power Systems, IEEE Transactions, vol. 24, no. 3, pp. 1537 - 1546, Aug. 2009.

[33] A. Arulampalam, G. Ramtharan, N. Caliao, J. Ekanayake and N. Jenkins," Simulated Onshore-Fault Ride Through of Offshore Wind Farms Connected 
Through VSC HVDC," Wind Engineering, vol. 32, no. 2, pp. 103-114, 2008.

[34] J. Sjolte, G. Tjensvoll, and M. Molinas, "Power [49] collection from wave energy farms," Applied Science. 3(2), pp. 420-436, 2013.

[35] A. Blavette, D. L. O'Sullivan, T.W. Lewis, and M. G. Egan, "Dimensioning the equipment of a wave farm: Energy storage and cables," in Proc. EVER, Mar. 2013, pp. 1-9.

[36] M. Molinas, O. Skjervheim, B. Sørby, P.Andreasen, S. Lundberg and T. Undeland, "Power Smoothing by [51] Aggregation of Waver Energy Converters for Minimizing Electrical Energy Storage Requirements", Proceedings of the 7th European Wave and Tidal Energy Conference, Porto, Portugal, 2007.

[37] S. Bruscaa, F. Cucinottaa, A. Galvagnoa, R. Lanzafameb, S. Maurob, and Michele Messinab, "Oscillating water column wave energy converter by [53] means of straight-bladed Darrieus turbine,' Elsevier Science Direct Journal, 82(1) pp. 766 - 773, 2015.

[38] M. P. Bahrman, J. G. Johansson, and B. A. Nilsson, "Voltage source converter transmission technologiesthe right fit for the application,' in Power Engineering meeting, July 2003, pp. 1840-1847.

[39] ABB, "Its time to connect," Company Report, 2008.

[40] C. Jones, "'Wind Farm Connection and Design Issues,' IET Round 3 Seminar, Manchester, UK, Presentation slides, 2012.

[41] T. Ramesh, and A.K. Panda, "Direct flux and torque control of three Phase induction motor drive using PI and fuzzy logic controllers for speed regulator and low torque ripple,' in Engineering and Systems Students Conf., pp. 1-6, March 2012.

[42] J. Machowski, J. W. Bialek and J. R. Bumby "Power System Dynamics Stability and Control", Second Edition, Chichester, UK: John Wiley \& Sons, Ltd., 2009.

[43] A. E. Madina, "Compliance verification methodology for renewable generation integration. Application to Island power Grids,' PhD dissertation, University of the Basque Country, Denmark, 2015.

[44] A. S. Soumya, and G.K. Purushothama, "Case study of Hysteresis and PI control as applied to Engine Coolant Temperature Control and Proposal of a combination Control logic," in Computing, Electronics and Electrical Technologies Conf., pp. 489-494, March 2012.

[45] C. Parker, S. Cowdroy and S. White (2006) BWEA GB Grid Code Representation: Applying the GB Grid Code Offshore- An Econnect Project No: 1484

[46] Alstom Grid, HVDC - Connecting to the future: Published by Alstom Grid, 2010.

[47] D.V. Hertem, O. Gonis-Bellmunt and J. Liang (2016) HVDC Grids: For Offshore and Supergrid of the future.

[48] Wind Turbines Connected to Grids with Voltages above $100 \mathrm{kV}$ - Technical regulation for the properties and the regulation of wind turbines, 144 Regulation TF
3.2.5, registered with the Danish Energy Authority on Dec 3, 2004.

S. Meier, "Novel voltage source converter based HVDC transmission system for offshore wind farms," Ph.D. dissertation, Dept. Electr. Eng., Royal Inst. Technol., Stockholm, Sweden, 2005.

[50] P.J. Tavner, "Studies in Electrical Machines \& Wind Turbines associated with developing Reliable Power Generation,' PhD thesis, Durham University, Durham, 2012.

S. Cole, J. Beerten, and R. Belmans, "Generalized dynamic VSC MTDC model for power system stability studies", Power Systems, IEEE Transactions on, vol. 25, no. 3, pp. $1655-1662$, August 2010.

[52] L. Shen, "Model Integration and Control Interaction Analysis of AC/VSC HVDC Systems," Ph.D. Thesis, The University of Manchester, 2015.

CIGRE WG B4.52 "HVDC Grid feasibility study" CIGRE brochure 533, April 2013.

[54] A. J. Beddard, "Factors Affecting the Reliability of VSC-HVDC for the Connection of Offshore Windfarms," PhD thesis, The University of Manchester, UK, 2014.

[55] Ø. Rui, C. O* hle'n, J. Solvik, J. Thon, K. Karijord, and T. Gjengedal, "Design, operation and availability analysis of a multi-terminal HVDC grid - a case study of a possible offshore grid in the Norwegian Sea," in IEEE Trondheim PowerTech 2011, pp. 1-7, June 2011. Cigre Working Group B1.10, "Update of Service Experience of HV Underground and Submarine Cable Systems," Working Group Brochure, 2009.

[57] A. A. Jamshidifar, and D. Jovic, "3-Level cascaded voltage source converters controller with dispatcher droop feedback for direct current transmission grids," Generation, Transmission \& Distribution, IET journal, vol. 9, no 6, pp. 571 - 579, 2015. 